Gabriela Nava

Cristina Múgica

\title{
Presentación
}

\section{Introduction by the Editors}

En el artículo que abre el Dossier, "Preguntas, configuraciones, andanzas en Cervantes", de este número de Acta Poetica, "Apostillas a un diálogo (entreoído) sobre la locura en el Quijote de 1615", Gustavo Illades explica que, en su pregunta por la locura de don Quijote, Mauricio Molho insiste en la importancia de pensarla como precartesiana, esto es, antes de una oposición radical entre razón y locura con la que Descartes inaugura la conciencia moderna. Así, la razón en el mundo de don Quijote es una no-locura, cordura, discreción, juicio que se identifica con la experiencia y se contrapone a la poesía y la fabulación.

Con la cercanía de la muerte, afirma Molho, declina asimismo, en la imaginación inflamada del hidalgo, la fábula de la caballería. También Margit Frenk se pregunta por la condición del personaje en el momento de su muerte y señala indicios textuales que apuntan a la locura definitiva del protagonista.

El artículo concluye con la propia pregunta del autor en el contexto del diálogo que ha ido siguiendo. Esta pregunta se plantea en la última escena de la novela ante las palabras de la instancia diegética, de Cide Hamete Benengeli, del personaje mismo en su lecho de muerte, donde este último se declara cuerdo y se autonombra Alonso Quijano el Bueno. En el repudio por las novelas de caballerías y la avidez por los libros de devoción cristiana, encuentra Illades "un nuevo avatar del lector in- 
saciable cuya vocación mimética lo proyectaría a identificarse esta vez con personajes sacros".

Molho entiende el Quijote como una búsqueda agónica de la razón a partir de las sinrazones del protagonista. Ahora bien, distinta de la razón cartesiana, la razón cervantina propia del libro, y ya no del personaje, asevera Illades, no será deducida, sino encontrada en la medida de la experiencia de la obra misma. Una aventura escritural que producirá un lector crítico.

En el artículo "Sobre el héroe geminado en Tolstói y Cervantes", Olga Svetlakova se propone delinear cronotópicamente la imagen geminada de Pierre/Andréi en Guerra y paz para compararla con el héroe geminado del Quijote.

Siguiendo a la autora, el Quijote se produce en los albores de la Edad Moderna, e implica a la vez la circularidad cósmico-mistérica, por ejemplo, en la figura de Sancho Panza, asociada con el ciclo mitológico agrario de la fertilidad y la cultura carnavalesca, y la vertical de la individualidad trágica del cuerpo y las acciones de don Quijote que se oponen a la primera.

En la novela de Tolstói, Pierre Bezújov aparece como un gran cuerpo, pesado, húmedo y perplejo, al que se contrapone la seca verticalidad de la acción personal del príncipe Andréi, que encuentra su sentido en la trascedencia.

En su nítido artículo "El caballero andante y su itinerario. Viaje y muerte de don Quijote", Nieves Rodríguez Valle da cuenta del andar, desviado de la tierra hollada de los caminos, del caballero que pretende convocar, en la soledad del campo, la aventura. No se trata de un viaje porque don Quijote no va a ninguna parte; a lo más, de un desplazamiento o, como lo ha caracterizado Paul Zumthor, de una errancia. Así va el caballero por la geografía manchega, como si fuera por la de las novelas de caballerías; por el bosque y la corte; por los prados, valles y cuevas.

Ahora bien, a decir de la autora, el Quijote comparte con la narrativa de viajes cuatro momentos: partida, travesía, encuentro y retorno. Las tres partidas se suscitan debido al deseo de aventuras y se producen sin anuncio alguno, casi en celada. En cuanto a la travesía, en contraste con los desplazamientos fantásticos de las novelas de caballerías, la pareja 
andante camina o cabalga y a su paso también conversa. En cuanto a los regresos, se asocian con las derrotas, y si don Quijote retorna a su aldea dos veces conducido por otros, la tercera, después de su derrota a manos del Caballero de la Blanca Luna, entra a su pueblo por propio pie en cumplimiento del código caballeresco.

Dentro de la sección Varia, Fernando Rodríguez Mansilla escribe sobre la interesante escritora María de Zayas, nacida en 1590, estableciendo las influencias del género picaresco en la novela Amar sólo por vencer y también el discurso protofeminista que plantea.

Refiere el autor que el tema de la novela se asemeja al de El pícaro amante de Camerino, donde una mujer rica que aspira a la nobleza acaba siendo seducida por un varón plebeyo, si bien el tema del varón travestido para llegar a la dama proviene de la novella italiana. En el caso específico de Amar sólo por vencer, el travestista no es un auténtico caballero galante, sino un pícaro, con lo que se produce un doble engaño.

Siguiendo a Rodríguez Mansilla, Amar sólo por vencer presenta el tema del poder, porque trata de la burla o el sometimiento de una dama noble. Y si bien el pícaro nunca se confunde con el valentón, matachín o germano, en la medida en que reprime la violencia a través del humor, el engaño en el caso de la novela desemboca en una tragedia a la italiana. Ahora bien, el pícaro, suerte de Proteo, logra escapar, pero Laurela, la protagonista, quedará atrapada en una violencia feroz que la llevará a la muerte. De esta manera denuncia Zayas la violencia contra las mujeres en la sociedad patriarcal.

En su interesante artículo "Intertextualidad narrativa: cómo Pacheco se apropia de The Go-Between", Jorge Alcázar aborda el tema de la intertextualidad, a través de una comparación entre The Go-Between (1953) de H. P. Hartley y Las batallas en el desierto (1981) de José Emilio Pacheco. También llamada adaptación, apropiación o interrelación entre hipotexto e hipertexto, la reescritura, señala el autor, es una característica de la narrativa de la posmodernidad, en ocasiones no exenta de polémica, como en el caso de Last Orders de Graham Swift y su adaptación de As I Lay Dying de William Faulkner.

De esta manera, el artículo señala elementos de la cautivadora novela de Pacheco tomados de The Go-Between que también narra el enamoramiento de un niño hacia una mujer mayor, y constituye una reconstruc- 
ción a dos voces: la del niño en el pasado y la del adulto en el presente de la enunciación, del inicio del siglo xx en el condado de Norfolk, como Las batallas en el desierto nos transporta, también en el contrapunto de la madurez y la inocencia, al periodo alemanista, tal como se viviera en la ciudad de México.

La sección Apuntes inicia con el espléndido ensayo "Volver a nombrar el mundo" de Jorge Gutiérrez Reyna, en el que el autor, con Eliot y Borges, pero también con Spitzer, Frenk, Benveniste y Pedro Salinas, nos habla de la acción quijotesca como una forma de escritura, una nueva manera de nombrar el mundo. Así, va explicando los híbridos lingüísticos, la palabra reveladora de aspectos inusitados de las cosas, la capacidad del lenguaje para erigir un mundo de la nada, el acto de nombrar como acto de poeta y el poder de la palabra para convocar lo enunciado.

En su trabajo "El loco amor como enfermedad mental. Los cuatro humores en el Arcipreste de Talavera o Corbacho de Alfonso Martínez de Toledo", Ángel Trejo entiende este libro como un intento de explicar a los hombres, y después a las mujeres, cómo protegerse del loco amor o amor hereos, enfermedad que mata el cuerpo y condena el alma. Siguiendo a Trejo, en contraste con el Libro de buen amor y su tratamiento ambiguo y jocoso del loco amor, la inequívoca condena de $E l$ Corbacho se dirige no sólo al acto sexual, sino también al deseo mismo.

El número concluye con la puntual reseña de David Galicia Lechuga a la antología Óyeme con los ojos: Poesía visual novohispana de Jorge Gutiérrez Reyna. 